\title{
Pengaruh Reputasi Underwriter, Underpricing, Financial Leverage Dan Profitabilitas Terhadap Kinerja Initial Public Offering (IPO)
}

\author{
Putri Amelia \\ Fajri Adrianto \\ Jurusan Manajemen, Fakultas Ekonomi, Universitas Andalas \\ Limau manis, Padang, Indonesia
}

\begin{abstract}
Pendanaan perusahaan dapat dilakukan dengan cara menjual saham di pasar modal. Perusahaan yang memilih untuk menjual sebagian kepemilikannya kepada masyarakat luas (go public) untuk pertama kalinya lebih dikenal dengan istilah Penawaran Umum Perdana atau Initial Public Offering (IPO). Tujuan dari penelitian ini adalah untuk melihat pengaruh Reputasi Underwiter, Underpricing, Financial Leverage dan Profitabilitas terhadap kinerja saham IPO. Kinerja saham diukur dalam periode waktu 1 bulan (Y1), 3 bulan (Y2), 6 bulan (Y3), 12 bulan (Y4) untuk melihat return/ kinerja disetiap periode waktu yang telah ditetapkan peneliti. Populasi dalam penelitian ini adalah semua perusahan yang terdaftar di prospektus BEI tahun 2016-2018, teknik pengambilan sampel non probability sampling dengan metode purposive sampling dan didapatkan sampel 54 perusahaan yang sesuai dengan kriteria penelitian. Jenis penelitian kuantitatif, jenis data sekunder, dengan tipe investigasi korelasional. Data analisis diolah menggunakan aplikasi STATA versi 15. Berdasarkan hasil analisis reputasi underwriter dan profitabilitas berpengaruh negatif dan tidak signifikan terhadap kinerja saham perusahaan yang melakukan IPO di BEI, underpricing berpengaruh positif dan tidak signifikan terhadap kinerja saham perusahaan yang melakukan IPO di BEI, dan financial leverage berpengaruh negatif dan signifikan terhadap kinerja saham perusahaan yang melakukan IPO di BEI.
\end{abstract}

Keyword: Reputasi underwriter, underpricing, financial leverage, profitabilitas, initial public offering (IPO), kinerja/ returnsaham

\section{Latar Belakang}

Persaingan terjadi dalam berbagai aspek kehidupan, terkhususnya dalam bidang bisnis, karena sudah tidak ada lagi batasan antara satu negara dengan negara yang lain. Perusahaan tentu saja membutuhkan dana yang besar agar perusahaan berkembang menjadi lebih besar dan tidak kalah saing dengan yang lain. Pendanaan bisa didapatkan yaitu dengan menjual saham di pasar modal, obligasi dan derivatifnya juga sekuritas lainnya untuk diperdagangkan di bursa efek ataupun pasar modal. Apabila perusahaan memilih untuk menjual sset an kepemilikannya kepada masyarakat luas (umum)/ investor (go public) maka untuk pertama kalinya adalah melalui sekuritas atau saham yang diterbitkan, hal ini lebih dikenal dengan istilah Penawaran Umum Perdana atau Initial Public Offering (IPO).

Initial Public Offering (IPO) merupakan salah satu alternatif pendanaan dengan cara meningkatkan ekuitas kepemilikan melalui menawarkan efeknya yaitu saham, obligasi, dan surat-surat berharga lainnya kepada masyarakat umum atau public (Gunawan \& Jodin, 2015). Pelaksanaan IPO melibatkan tiga pihak yang akan terlibat secara langsung yaitu emiten, underwrtiter, dan investor. Pada saat perusahaan malakukan IPO, umumnya para investor akan memiliki informasi yang terbatas seperti yang diumumkan atau diterbitkan dalam prospektus Informasi yang terbatas menjadi permasalahan dalam melakukan IPO salah 
satunya yaitu terjadi asimetri informasi. Teori asimetri informasi ini terjadi karena distribusi informasi yang tidak merata antara investor dengan emiten, underwriter dengan calon emiten (Budiman, 2019).

Citra atau penampilan yang kuat di aftermarket tidak hanya akan menjadi penjamin emisi (underwriter) untuk mendapatkan keuntungan lebih lanjut dengan menggunakan opsi keseluruhan penempatan mereka, akan tetapi juga memperkuat posisi mereka di pasar IPO. Fenomena kinerja jangka panjang yang memburuk pasca IPO ini terjadi di banyak negara, baik di pasar modal negara maju maupun negara berkembang termasuk Indonesia. Menurut Ritter (1991), dalam Kusumawati (2016), kinerja IPO jangka panjang berkinerja buruk dikarenakan investor yang sangat optimis membeli saham IPO dengan harga yang tinggi, dalam jangka panjang harga saham akan dikoreksi kembali ke nilai aktual, sehingga pengembalian menjadi rendah. Hal inilah yang menyebabkan kinerja saham IPO mengalami kinerja yang kurang baik dalam jangka panjang.

Pengembalian dalam IPO yang paling sering terjadi salah satunya yaitu underpricing. Underpricing adalah fenomena yang sering terjadi dan umum terjadi di pasar modal dunia termasuk Indonesia. Underpricing bisa terjadi akibat harga saham IPO yang ditetapkan sangat rendah, sebab harga yang terjadi di pasar sekunder telah mencerminkan harga dalam kondisi baik atau full information. Besarnya underpricing diukur dengan initial return yaitu selisih harga saham di pasar sekunder akan lebih tinggi dibandingkan dengan harga saham pada saat penawaran perdana (Nur aini, 2013). Underpricing juga sering terjadai karena akibat ketidakpastian harga saham di pasar perdana.

Kinerja keuangan perusahaan dapat dilihat dari financial leverage yang diproyeksikan oleh DER suatu perusahaan, dengan membagi total debt dengan total Shareholder's Equity. Financial leverage dapat menunjukkan kemampuan perusahaan dalam membayar hutang dengan modal yang dimiliki perusahaan, sehingga dapat mencerminkan resiko dari suatu perusahaan (Wijayanto, 2010). Perusahaan yang financial leverage tinggi akan cenderung lebih menggunakan dana hasil IPO untuk membayar hutang, daripada untuk kegiatan investasi yang berguna dalam melakukan ekspansi baru di perusahaan (Wijayanto, 2010). Investor lebih cenderung akan menghindari saham-saham perusahaan yang memiliki nilai DER (leverage) yang tinggi (Darpius, Agustin2, \& Sari, 2019).

Rasio aktivitas perusahaan juga dapat menjadi patokan investor untuk melihat seberapa besar efisiensi penggunaan sset perusahaan. Profitabilitas akan tidak baik apabila dana yang tersedia cukup besar, yang artinya dana perusahaan tidak mempergunakan untuk investasi pada aset dan dinilai kurang produktif. Jika pertumbuhan laba atau keuntungan perusahaan baik maka akan dapat meningkatkan nilai perusahaan (Andayani, Wiksuana, \& Sedana, 2017).

\section{Pengembangan Hipotesis}

\section{Pengaruh reputasi underwriter terhadap kinerja perusahaan yang melakukan IPO di BEI}

Pada penawaran perdana (IPO) harga saham ditentukan berdasarkan kesepakan antara pihak emiten (perusahaan) dengan penjamin emisi efek (underwriter). Sebagai pihak yang membutuhkan dana tentunya pihak emiten menginginkan harga perdana yang tinggi, sebaliknya pihak penjamin emisi akan berusaha untuk meminimalisir risiko yang ditanggungnya. Dengan permintaan emiten yang menginginkan harga pada saham perdana tinggi, saham pada saat IPO cenderung tidak laku dijual, dalam tipe penjamin full comiment, pihak underwriter akan membeli saham yang tidak dijual di pasar perdana dan hal tersebut membuat underwriter tidak berkeinginan untuk membeli saham yang tidak laku tersebut. Salah satu upaya yang dapat dilakukan ialah dengan melakukan negosiasi dengan emiten, 
agar saham tersebut dijual dengan harga yang tidak terlalu tinggi, bahkan cenderung underprice (Surbakti, 2012).

Penelitian Murtini, (2013) menemukan underwriter berpengaruh negatif terhadap underpricing, yang mana artinya apabila calon emiten menggunakan penjamin emisi yang baik reputasinya, maka tingkat underprice semakin kecil. Semakin berpengalaman dan mempunyai citra yang bagus underwriter maka dapat memberikan saran yang lebih baik dalam penentuan harga saat IPO dan dapat ditetapkan semakin mendekati harga intrinsinya. Apabila harga IPO mendekati harga intrinsiknya, maka harga saham tersebut saat dijual di pasar sekunder hanya mengalami sedikit kenaikan harga. Apabila investor memegang saham jangka pendek akan mendapat capital gain, akan tetapi bukan untuk pemegang saham jangka panjang, maka dari itu calon investor perlu memperhatikan underwriter perusahaan tersebut.

Carter, Dark, \& Singh (1998) dalam penelitiannya menemukan bahwa kinerja perusahaan yang ditangani oleh penjamin emisi yang lebih bergengsi mengurangi kemungkinan terburuk (saham tidak terjual) dari saham IPO relatif pada pasar selama periode holding 3 tahun. Artinya hal ini menunjukkan adanya peningkatan kinerja yang dikarenakan underwriter yang merupakan highly bank investment, karena adanya tambahan modal, sesuai dengan penelitian Surbakti (2012), yang menyebutkan bahwa saham yang tidak terjual akan dibeli oleh underwriter akan tetapi underwriter sebisa mungkin untuk bernegosiasi agar harga saham diturunkan. Hal ini menyebabkan, semakin tinggi reputasi underwriter maka semakin rendah initial retun pada saat IPO, begitu juga sebaliknya, semakin rendah reputasi underwriter maka semakin tinggi tingkat initial reuturn pada saat IPO.

IPO yang dikelola oleh bankir investasi prestise tinggi cenderung memiliki pengembalian awal yang lebih kecil dan pengembalian jangka panjang yang lebih negatif daripada IPO yang ditangani oleh penjamin emisi reputasi rendah. Mereka menggunakan modal bank investasi sebagai proxy untuk prestise hasil dari penelitian (Carter et al., 1998). Bahkan dalam penelitian Santoso \& Wuryani, (2013) menunjukkan reputasi underwriter tidak mempunyai pengaruh yang signifikan terhadap initial return, karena penggunaan underwriter yang memiliki reputasi baik tidak memberikan sinyal bagi investor untuk memperkirakan nilai untuk suatu perusahan yang melakukan IPO. Hal ini mengindikasikan bahwa penggunaan underwriter dengan reputasi baik tidak mengurangi ketidakpastian, yang tidak diungkapkan oleh informasi yang terdapat didalam prospektus. Berdasarkan uraian diatas, maka hipotesis pertama yaitu:

H1: Reputasi underwriter berpengaruh negatif dan tidak signifikan terhadap kinerja perusahaan yang melakukan IPO di BEI

\section{Pengaruh underpricing terhadap kinerja perusahaan yang melakukan IPO di BEI}

Fenomena underpricing juga akan terjadi pada IPO dalam jangka panjang. Underpricing menjadi hal yang menarik bagi para peneliti karena dialami sebagian besar pasar modal di dunia. Underpricing ialah suatu keadaan dimana harga saham penawaran perdana lebih rendah dibanding ketika diperdagangkan di pasar sekunder, yang mana harga yang akan ditawarkan pada penawaran perdana ke publik berdasarkan kesepakatan antara emiten dengan underwriter dan harga saham yang terjadi di pasar sekunder berasal dari hasil mekanisme penawaran dan permintaan (J. R. Ritter, 1991).

Dalam penelitian A. Chen et al., (2010) mengenai pengukuran terhadap kinerja jangka panjang dari saham IPO yang beradai di Taiwan, menemukan hasil yaitu kinerja jangka panjang saham IPO menunjukkan terjadinya underperformed dan yang sering terjadi pada kinerja saham IPO dimungkinkan karena adanya miss specification dari model pengukuran kinerja itu sendiri. 
Bukti-bukti empiris yang telah ada yang membahas mengenai performa jangka panjang saham IPO dari berbagai negara di luar Asia tenggara, menunjukkan bahwa negatif initial return pada umumnya akan diikuti dengan adanya underperformance dalam kinerja jangka panjang. Florentina, (2014) menyimpulkan abnormal return pada saham IPO jangka panjang adalah negatif dan menunjukkan kinerja saham pada jangka panjang mengalami underperformed. Price return pada IPO berkorelasi negatif terhadap initial return atau keuntungan awal dan menyarankan pasar unutk mengevaluasi juga mengkoreksi overvaluation (underpricing) atas saham IPO pada saat intial return terjadi. Return tersebut dapat meunjukkan initial return bisa terjadi pada saat pemegang saham (investor) membeli saham pada harga perdana (offering price). Berdasarkan uraian diatas, maka hipotesisnya yaitu:

$\mathrm{H} 2$ : Underpricing berpengaruh negatif dan tidak signifikan terhadap kinerja perusahaan yang melakukan IPO di BEI

\section{Pengaruh Profitabilitas terhadap kinerja perusahaan yang melakukan IPO di BEI}

Rasio laba bersih setelah pajak terhadap total penjualan atau yang biasa disebut dengan profitabilitas yang akan diukur dengan ROA (Return On Asset), menunjukkan kinerja keuangan perusahaan dalam menghasilkan laba bersih atas total penjualan bersih yang didapatkan oleh perusahaan. Apabila perusahaan menghasilkan laba bersih atas penjualan bersihnya semakin meningkat, maka hal ini akan menjadikan cerminan yang baik yaitu, bentuk dividen gain atau capital gain yang akan diterima oleh investor atau pemegang saham akan semakin besar. Jika profitabilitas yang didapatkan perusahaan meningkat, dengan demikian para investor akan tertarik untuk menanamkan modalnya pada perusahan tersebut (Wijayanto, 2010).

Dalam jangka waktu 5 tahun pasca IPO, Apriliasari, (2013) melakukan penelitian dan menemukan hasil yaitu kemungkinan akan terjadi resiko kerugian perusahaan yang lebih tinggi, namun terdapat peluang untuk memperoleh profit yang besar pula terlebih jika perputaran aset tetap bersih untuk menciptakan penjualan atau pendapatan investasi mengalami perbaikan karena ada peningkatan dan rasio hutang jangka panjang yang masih menurun.

Return on asset memiliki pengaruh yang signifikan terhadap tingkat underpricing saham diterima. Semakin tinggi return on asset, semakin rendah tingkat underpricing, karena investor akan menilai perusahaan yang bersangkutan berkinerja dengan baik dan akan bersedia membeli saham perdananya dengan harga tinggi. Sehingga ROA berpengaruh signifikan terhadap underpricing (Gunawan \& Jodin, 2015).

Tingkat keuntungan memainkan peranan penting didalam penilaian prestasi kerja perusahaan dan sangat sering dijadikan patokan calon investor untuk menanamkan modalnya pada suatu perusahaan. Berdasarkan uraian diatas, maka hipotesis ketiga pada penelitian ini yaitu:

H3: Profitabilitas berpengaruh positif dan signifikan terhadap kinerja perusahaan yang melakukan IPO di BEI

\section{Pengaruh financial leverage terhadap kinerja perusahaan yang melakukan IPO di BEI}

Fluktuasi bisnis perusahaan dapat berdampak terhadap keuntungan pemilik ekuitas, apabila sebagian modal perusahaan dibiayai oleh hutang, maka dari itu kewajiban finance merupakan salah satu ukuran resiko perusahaan. Dalam penelitian Afriyeni \& Marlius, (2006) financial leverage akan memberikan konsekuensi signal yang tidak berpengaruh 
signifikan terhadap initial return saham yang disebabkan oleh fluktuasi. Sehingga variabel financial leverage kurang memberikan konsekuensi terhadap keputusan investor bertransaksi di pasar perdana.

Investor pada saham biasa pada umumnya akan memandang utang perusahaan sebagai cerminan kerugian investasi, namun diimbangi dengan potensial keuntungan dan leverage keuangan. Di pasar modal Indonesia tingkat leverage mempengaruhi keputusan investasi, semakin tinggi leverage suatu perusahaan maka, akan semakin tinggi pula resiko yang akan didapat perusahaan, hal ini terjadi karena apabila terdapat kemungkinan terburuk yaitu kemungkinan gagal bayar dari perusahaan untuk hutang perusahaan akan berpengaruh negative terhadap keputusan investasi di pasar perdana (Darpius et al., 2019). Karena hal itu para investor dalam mengambil keputusan saat berinvestasi pasti akan mempertimbangkan informasi mengenai financial ratio.

Financial leverage setelah dilakukkannya IPO mengalami penurunan dalam hasil penelitian Izfs \& Supriatna, (2019), penurunan ini memberikan tanda bahwa kondisi kinerja keuangan setelah IPO menjadi lebih baik. Wijayanto, (2010) menemukan financial leverage bengaruh positif dan tidak signifikan terhadap initial return karena hal yang sama dengan penjelasan penelitian Izfs \& Supriatna, (2019). Investor lebih cenderung akan menghindari saham-saham perusahaan yang memiliki nilai DER (leverage) yang tinggi (Darpius et al., 2019).

Tetapi leverage perusahaan yang menurun belum tentu lebih baik dalam long term performance, karena hal ini bisa terjadi peluang yang besar untuk obligasi dan prospek yang jauh lebih besar untuk investasi, keputusan perusahaan yang go public akan membuka peluang untuk biaya yang murah pada hutang jangka panjang. Maka dari itu hipotesis yang terakhir adalah:

H4: financial leverage berpengaruh negatif dan signifikan terhadap kinerja perusahaan yang melakukan IPO di BEI

\section{Metode Riset}

\section{Desain Penelitian}

Penelitian ini merupakan penelitian kuantitatif yang mana data akan dapat diukur ataupun dihitung secara langsung dan informasi dinyatakan dalam bentuk bilangan atau dalam bentuk angka, tujuan, pendekatan subyek, sampel, langkah penelitian, dan sumber data sudah jelas (Suliyanto, 2017). Penelitian ini menggunakan pengujian hipotesis yang akan membuktikan dan menjelaskan dugaan sementara yang telah peneliti sampaikan pada bab sebelumnya.

Dalam pengujian hipotesis, penulis menggunakan tipe investigasi korelasional, yang mana menginvestigasi faktor mana yang paling berkaitan atau berhubungan antara dua variabel yang sifatnya adalah kuantitatif. Unit analisis yang digunakan dalam penelitian ini adalah organisasi, mengambil data dari beberapa sektor manufaktur di Indonesia. Dan untuk menguji hasil dari hipotesis yang diajukan, variabel yang akan diteliti dalam penelitian ini diklasifikasikasikan menjadi variabel denependen, variabel independen dan juga variabel kontrol (Sekaran, Uma dan Bougie, R., 2017).

\section{Populasi dan Sampel}

Populasi dalam penelitian ini adalah seluruh perusahaan go public, saham perusahan yang terdaftar dalam prospektus Bursa Efek Indonesia melalui proses IPO, dalam rentang waktu dari Januari 2016 hingga Agustus tahun 2018. Terdapat 16 perusahaan pada tahun 2016, 25 perusahaan pada tahun 2017, dan 58 perusahaan pada tahun 2018. 
Teknik pengambilan data adalah non probability sampling yang mana teknik ini tidak memberikan kesempatan ataupun peluang yang sama bagi setiap unsur populasi untuk dipilih menjadi sampel. Sampel yang dipilih sesuai dengan variabel-variabel yang telah di tentukan pada penelitian ini.

Metode purposive sampling akan digunakan dalam pemilihan sampel di penelitian ini. Metode purposive sampling adalah suatu satuan sampling yang akan dipilih berdasarkan pertimbangan-pertimbangan tertentu yang sesuai dengan kriteria yang telah ditentukan, dengan tujuan untuk memperoleh satuan sampling yang memiliki karakteristik yang dikehendaki.

Sampel pada penelitian ini mempunyai kriteria sebagai berikut:

1. Laporan keuangan perusahaan IPO

2. Data harga saham saat hari pertama IPO

3. Data harga saham sebulan setelah IPO

4. Data harga saham enam bulan setelah IPO

5. Data harga saham setahun setelah IPO

6. Data harga saham pada saat penutupan

7. Harga dinyatakan dalam Rupiah (IDR)

Berdasarkan kriteria diatas, perusahaan yang melakukan IPO dan lengkap memenuhi syarat terdapat 11 perusahaan pada tahun 2016, 18 perusahaan pada tahun 2017, 25 perusahaan di tahun 2018, total perusahaan yaitu 54 perusahaan.

Jenis data yang akan peneliti gunakan yaitu data sekunder dan sumber data dalam penelitian ini akan diambil dari laporan keuangan perusahaan yang bersumber dari laman prospektus website Bursa Efek Indonesia www.idx.co.id. Secara spesifik, data yang digunakan dalam penelitian ini adalah harga perdana (offering price), harga penutupan (closing price) dan harga saham dalam kurun waktu 12 bulan untuk melihat kinerja perusahaan setelah perusahaan tersebut listing di BEI. 


\section{Operasional Variabel}

Variabel yang digunakan dalam penelitian ini ada variabel dependen dan variabel independen. Variabel dependen yaitu kinerja IPO yang dihitung dari sebulan setelah IPO, tiga bulan setelah IPO, enam bulan setelah IPO dan satu tahun setelah IPO. Variabel independen yaitu reputasi underwriter, underpricing, profitailitas, dan leverage dengan variabel kontrol asset.

Tabel 1

Definisi Operasional Variabel dan Pengukuran Variabel

\begin{tabular}{|c|c|c|c|}
\hline No & Keterangan & Definisi & Pengukuran \\
\hline 1. & $\begin{array}{l}\text { Variabel } \\
\text { Dependen }\end{array}$ & & \\
\hline & $\begin{array}{l}\text { Return } \\
\text { saham Long } \\
\text { term } \\
\text { performance } \\
\text { IPO }\end{array}$ & $\begin{array}{l}\text { Kinerja jangka } \\
\text { panjang pada } \\
\text { perusahaan yang } \\
\text { melakukan IPO } \\
\text { mengalami sering } \\
\text { mengalami } \\
\text { underperformance } \\
\text { disebabkan karena } \\
\text { perusahaan } \\
\text { memang memiliki } \\
\text { kinerja yang } \\
\text { buruk, adanya } \\
\text { informasi } \\
\text { asimetri, dan } \\
\text { berbagai } \\
\text { kesalahan dalam } \\
\text { pengukuran risiko } \\
\text { (Florentina, } \\
\text { 2014). Untuk } \\
\text { mengetahui } \\
\text { kinerja jangka } \\
\text { panjang } \\
\text { perusahaan pada } \\
\text { saat IPO, } \\
\text { penelitian ini akan } \\
\text { melihat return } \\
\text { pada hari pertama, } \\
\text { sebulan setelah } \\
\text { IPO, setelah tiga } \\
\text { bulan saham IPO, } \\
\text { setelah } 6 \text { bulan, } \\
\text { dan satu tahun } \\
\text { saham IPO. }\end{array}$ & $\begin{array}{l}\text { Return } 1 \text { month }(Y)=\frac{\text { Price } 1 \text { month }- \text { Offering Price }}{\text { Offering Price }} \\
\text { Return } 3 \text { month }(Y)=\frac{\text { Price } 3 \text { month }- \text { Offering Price }}{\text { Offering Price }} \\
\text { Return } 6 \text { month }(Y)=\frac{\text { Price } 6 \text { month }- \text { Offering Price }}{\text { Offering Price }} \\
\text { Return } 12 \text { bulan }(Y)=\frac{\text { Price } 12 \text { bulan }- \text { Offering Price }}{\text { Offering Price }}\end{array}$ \\
\hline 2 & $\begin{array}{l}\text { Variabel } \\
\text { Independen }\end{array}$ & & \\
\hline a. & $\begin{array}{l}\text { Reputasi } \\
\text { Underwriter }\end{array}$ & $\begin{array}{l}\text { Reputasi } \\
\text { underwriter yang } \\
\text { baik akan } \\
\text { memberikan } \\
\text { sinyal positif atau } \\
\text { sinyal baik kepada } \\
\text { pasar, sebab pasar } \\
\text { relatif lebih } \\
\text { mengenal }\end{array}$ & $\begin{array}{l}\text { Menggunakan variabel dummy, dimana memberi nilai } 1 \text { untuk } \\
\text { underwriter yang termasuk kedalam } 20 \text { most active brokerage } \\
\text { houses } \text { www.idx.co.id dan dalam } 10 \text { besar dalam website www.cnbc } \\
\text { indonesia.com dan nilai } 0 \text { bagi yang tidak termasuk berdasarkan } \\
\text { nilai perdagangan. }\end{array}$ \\
\hline
\end{tabular}




\begin{tabular}{|c|c|c|c|}
\hline & & $\begin{array}{l}\text { underwriter yang } \\
\text { bereputasi baik, } \\
\text { dan pasar akan } \\
\text { lebih percaya } \\
\text { bahwa } \\
\text { underwriter } \\
\text { dengan reputasi } \\
\text { baik tidak akan } \\
\text { menjamin } \\
\text { perusahaan yang } \\
\text { berkualitas } \\
\text { rendah, atau } \\
\text { perusahaan } \\
\text { dengan kinerja } \\
\text { yang tidak bagus. } \\
\text { Jika semakin } \\
\text { tinggi reputasi } \\
\text { underwriter maka } \\
\text { akan } \\
\text { mencerminkan } \\
\text { resiko perusahaan } \\
\text { IPO tersebut } \\
\text { rendah serta } \\
\text { rendah pula } \\
\text { tingkat } \\
\text { ketidakpastian } \\
\text { saham dimasa } \\
\text { yang akan datang, } \\
\text { sehingga tingkat } \\
\text { underpricing akan } \\
\text { rendah pula (Aini, } \\
\text { 2013). }\end{array}$ & \\
\hline b. & $\begin{array}{l}\text { Underpricing } \\
\text { diukur } \\
\text { dengan } \\
\text { Initial return }\end{array}$ & $\begin{array}{l}\text { Initial return yaitu } \\
\text { selisih harga } \\
\text { saham di pasar } \\
\text { sekunder akan } \\
\text { lebih tinggi } \\
\text { dibandingkan } \\
\text { dengan harga } \\
\text { saham pada saat } \\
\text { penawaran } \\
\text { perdana. (Aini, } \\
\text { 2013). }\end{array}$ & $I R i, t=\frac{\text { Closing Price } i, t-\text { Offering Price } i, 0}{\text { Offering Price } i, 0} \times 100$ \\
\hline c. & $\begin{array}{l}\text { Profitabilitas } \\
\text { Diukur } \\
\text { dengan } \\
\text { Return On } \\
\text { Asset }\end{array}$ & $\begin{array}{l}\text { Profitabilitas } \\
\text { dapat } \\
\text { menunjukkan } \\
\text { besar kecilnya } \\
\text { tingkat laba yang } \\
\text { diperoleh dari } \\
\text { penjualan maupun } \\
\text { investasi } \\
\text { perusahaan, } \\
\text { semakin bagus } \\
\text { rasio profitabilitas } \\
\text { suatu perusahaan, } \\
\text { maka semakin } \\
\text { baik pula } \\
\text { kemampuannya }\end{array}$ & $R O A=\frac{E B I T}{\text { Total Aset }} \times 100$ \\
\hline
\end{tabular}




\begin{tabular}{|c|c|c|c|}
\hline & & $\begin{array}{l}\text { dalam } \\
\text { menggambarkan } \\
\text { tingginya } \\
\text { perolehan } \\
\text { keuntungan } \\
\text { perusahaan } \\
\text { (Darpius et al., } \\
\text { 2019). }\end{array}$ & \\
\hline d. & $\begin{array}{l}\text { Financial } \\
\text { Leverage }\end{array}$ & $\begin{array}{l}\text { Kinerja keuangan } \\
\text { perusahaan dapat } \\
\text { dilihat dari } \\
\text { financial leverage } \\
\text { yang } \\
\text { diproyeksikan } \\
\text { oleh DER suatu } \\
\text { perusahaan, } \\
\text { dengan membagi } \\
\text { total debt dengan } \\
\text { total } \\
\text { Shareholder's } \\
\text { Equity. Financial } \\
\text { leverage dapat } \\
\text { menunjukkan } \\
\text { kemampuan } \\
\text { perusahaan dalam } \\
\text { membayar hutang } \\
\text { dengan modal } \\
\text { yang dimiliki } \\
\text { perusahaan, } \\
\text { sehingga dapat } \\
\text { mencerminkan } \\
\text { resiko dari suatu } \\
\text { perusahaam } \\
\text { (Wijayanto, } \\
\text { 2010). }\end{array}$ & $D E R=\frac{\text { Total hutang }}{\text { Total equity }}$ \\
\hline 3. & $\begin{array}{l}\text { Variabel } \\
\text { Kontrol }\end{array}$ & Log total aktiva & LogASSET \\
\hline
\end{tabular}




\section{HASIL PENELITIAN}

\section{Pengaruh reputasi underwriter terhadap kinerja perusahaan yang melakukan IPO di BEI}

Pada uji parsial dalam jangka waktu 1 bulan, 3 bulan dan 12 bulan, menguji pengaruh reputasi underwriter terhadap kinerja perusahaan yang melakukan IPO di Bursa Efek Indonesia mendapatkan hasil semuanya berpengaruh negatif dan tidak signifikan. Nilai koefisien variabel reputasi underwriter pada periode 1 bulan (Y1) sebesar -0.7999952 dengan tingkat signifikan sebesar 0.069 , periode 3 bulan nilai koefisien sebesar -0.7748956 dengan tingkat signifikan 0.094 , pada periode 12 buan nilai koefisien sebesar -1.131528 dengan tingkat signifikansi 0.075. Berbeda pada periode waktu 6 bulan, variabel reputasi underwriter berpengaruh negatif dan signifikan dengan nilai koefisien sebesar -0.8477592 dan tingkat signifikan 0.042 lebih kecil dari 0.05 .

Tabel 2

Uji t parsial variable reputasi underwriter kinerja perusahaan yang melakukan IPO tahun 2016-2018

\begin{tabular}{|l|c|c|c|l|}
\hline Variabel RU & Koefisien & $\mathrm{t}$ & $\mathrm{P}>|\mathrm{t}|$ & \multicolumn{1}{|c|}{ Hasil } \\
\hline Y1 & -0.7999952 & -1.86 & 0.069 & Tidak Signifikan \\
\hline Y2 & -0.7748956 & -1.71 & 0.094 & Tidak Signifikan \\
\hline Y3 & -0.8477592 & -2.09 & 0.042 & Signifikan \\
\hline Y4 & -1.131528 & -1.82 & 0.075 & Tidak Signifikan \\
\hline
\end{tabular}

Sumber: Hasil Pengolahan Data Stata 15

Selain menguji secara parsial, secara simultan pun variabel reputasi underwriter juga diuji dalam periode waktu yang dipisah. Pada periode waktu 1 bulan (Y1) didapatkan Prob > F sebesar 0.0001, periode waktu 3 bulan (Y2) didapatkan Prob > F sebesar 0.0000, pada periode waktu 6 bulan (Y3) didapatkan Prob > F sebesar 0.0000, pada periode waktu 12 bulan didapatkan Prob > F sebesar 0.0035, semua nilai signifikansi kecil dari 0.005 dengan nilai koefisien negatif, yang mana artinya reputasi underwriter berpengaruh signifikan secara serentak terhadap kinerja perusahaan IPO.

Semua periode waktu dari 1 bulan, 3 bulan dan 12 bulan mempunyai tingkat signifikansi yang besar dari 0.05 pada uji $t$, artinya variabel independen reputasi underwriter dan variabel dependen (kinerja perusahaan yang melakukan IPO di BEI ) tidak signifikan. Nilai koefisien semua periode waktu juga menunjukkan nilai yang negatif yang mana hal ini berarti variabel reputasi underwriter menunjukkan pengaruh negatif dan tidak signifikan terhadap kinerja perusahaan yang melakukan IPO di Bursa Efek Indonesia.

Sejalan dengan tugas dari underwriter adalah sebagai penjamin emisi yang akan memperjual belikan saham yang dikeluarkan oleh perusahaan. Terjadinya hubungan negatif dan tidak signifikan pada penelitian ini dapat disebabkan oleh kesalahan estimasi yang dilakukan oleh underwriter saat penetapan harga IPO, akibatnya terjadi underperformance dalam jangka panjang. Hubungan yang tidak signifikan juga dapat terjadi karena upaya yang dilakukan underwriter untuk mencegah terjadinya saham tidak terjual adalah dengan menetapkan harga yang tidak terlalu tinggi dengan tujuan agar semua saham terjual pada saat IPO, akan tetapi menimbulkan resiko underpricing yang semakin tinggi.

Reputasi underwriter tidak mempunyai pengaruh yang signifikan terhadap kinerja perusahaan yang melakukan IPO, karena dengan penggunakan underwriter dengan reputasi baik tidak menjamin dalam mengurangi ketidakpastian bagi investor dan tidak menjamin kebenaran informasi yang diberikan perusahaan melalui prospektus. 
Hubungan yang negatif juga mengartikan bahwa reputasi underwriter mempunyai hubungan yang berlawanan arah dengan return kinerja perusahaan, IPO, Hubungan yang negatif dari variabel reputasi underwriter ini artinya, underwriter yang termasuk dalam 20 most active brokerage houses dan dalam 10 besar dalam website www.cnbc akan otomatis menurunkan tingkat initial return dan yang tidak termasuk kedalam 20 most active brokerage houses dan dalam 10 besar dalam website www.cnbc.com akan meningkatkan return, karena underwriter dengan reputasi yang tinggi akan lebih berani untuk memberikan harga yang tinggi, bahkan menentukan harga mendekati harga intrinsik, sebagai suatu konsekuensi dari kualitas penjaminnya.

Hasil dari penelitian ini konsisten dengan penelitian yang dilakukan oleh Lestari, Hidayat, \& Sulasmiyati (2015), Santoso \& Wuryani (2013) yang menemukan hasil penelitian serupa bahwa reputasi underwriter memiliki pengaruh negatif dan tidak signifikan terhadap initial return saham IPO. Berbeda dengan hasil yang didapatkan penelitian Murtini (2013), Purwanto \& Cahyaningrum (2019), Yuliani, Wahyuni, \& Bakar(2019), Assari, Juanda, \& Suprapti (2014) yang mengatakan bahwa reputasi underwriter berpengaruh negatif dan signifikan terhadap return.

\section{Pengaruh underpricing terhadap kinerja perusahaan yang melakukan IPO di BEI}

Pada periode waktu satu bulan diperoleh nilai koefisien sebesar 0.9981597 dengan tingkat signifikan sebesar 0.026 lebih kecil dari 0.05 , hal ini berarti bahwa bahwa ada pengaruh yang signifikan antara variabel independen terhadap variabel dependen pada periode 1 bulan. Nilai koefisien yang positif pada periode waktu satu hari ini mengartikan apabila investor membeli saham saat IPO dan menyimpannya selama satu bulan maka tingkat underprice saham akan semakin tinggi atau terjadi underpricing.

Tabel 3

Uji t parsial variable underpricing kinerja perusahaan yang melakukan IPO tahun 2016-2018

\begin{tabular}{|l|l|l|l|l|}
\hline Variabel UP & Koefisien & $\mathrm{t}$ & $\mathrm{P}>|\mathrm{t}|$ & Hasil \\
\hline Y1 & 0.9981597 & 2.30 & 0.026 & Signifikan \\
\hline Y2 & 0.4833772 & 1.06 & 0.296 & Tidak Signifikan \\
\hline Y3 & 0.1622999 & 0.40 & 0.694 & Tidak Signifikan \\
\hline Y4 & 0.3821814 & 0.61 & 0.545 & Tidak Signifikan \\
\hline
\end{tabular}

Sumber: Hasil Pengolahan Data Stata 15

Hal yang berbeda terjadi pada periode waktu 3 bulan (Y2) 6 bulan (Y3) dan 12 bulan (Y4) terjadi underpricing jika investor membeli saham saat IPO dan menyimpannya selama tiga bulan dengan nilai koefisien yang didapatkan sebesar 0.4833772 dengan tingkat signifikan sebesar 0.296 lebih besar dari pada 0.05, pada periode waktu 6 bulan (Y3) mendapat nilai signifikansi sebesar 0.1622999 dengan tingkat signifikan 0.694 lebih besar dari 0.05 , pada periode waktu 12 bulan nilai koefisien sebesar 0.3821814 dengan tingkat signifikan 0.545 lebih besar dari 0.05 artinya pada periode waktu 3 bulan, 6 bulan dan 12 bulan berpengaruh tidak signifikan terhadap initial return kinerja perusahaan yang melakukan IPO di Bursa Efek Indonesia.

Selain menguji secara parsial, secara simultan pun variabel underpricing juga diuji dalam periode waktu yang dipisah. Secara simultan pengujian menggunakan variabel kontrol aset 
ataupun tidak menggunakan variabel kontrol memperoleh hasil diperoleh Prob $>\mathrm{F}$ atau nilai simultan Pada periode waktu 1 bulan (Y1) didapatkan Prob > F sebesar 0.0001, periode waktu 3 bulan (Y2) didapatkan Prob > F sebesar 0.0000, pada periode waktu 6 bulan (Y3) didapatkan Prob > F sebesar 0.0000, pada periode waktu 12 bulan didapatkan Prob > F sebesar 0.0035, semua nilai signifikansi kecil dari 0.005 dengan nilai koefisien positif, yang mana artinya variabel underpricing berpengaruh signifikan secara serentak terhadap kinerja perusahaan IPO dan pengaruh positif juga mengartikan terjadi outperformance dalam jangka panjang. Underpricing merupakan suatu keadaan dimana saham akan memberikan return yang positif pada transaksi pasar sekunder setelah saham pada penawaran perdana, underpricing dapat disebabkan oleh perbedaan kepentingan dari pihak-pihak yang terkait dalam penawaran saham perdana.

Hasil penelitian ini tidak sepakat dengan penelitian Florentina (2014), Chan, Wang, \& Wei (2004), J. R. Ritter (1991), Y.S et al. (2010), Apriliasari (2013), Meidiaswati (2008), Florentina (2014), yang menyatakan underperformed pada kinerja perusahaan IPO, dan terjadi underpricing. Berbeda dengan penemuan Irfani (2011) yang menemukan hasil yang positif dalam jangka panjang pasca IPO terjadi outperformance dan underpricing dalam kinerja IPO.

\section{Pengaruh Profitabilitas terhadap kinerja perusahaan yang melakukan IPO di BEI}

Nilai koefisien ROA pada periode waktu 1 bulan sebesar -0.498195 dengan tingkat signifikansi 0.57 besar dari 0.05 . Pada waktu 3 bulan nilai koefisien variabel ROA sebesar 7577738 dengan tingkat signifikan 0.41 besar dari 0.05 , periode waktu 6 bulan nilai koefisien sebesar -0.7014037 dengan tingkat signifikan 0.400 besar dari 0.05 , pada periode 12 bulan nilai koefisien sebesar -0.9102826 dengan tingkat signifikan 0.475 besar dari 0.05 . Secara keseluruhan periode 1 bulan hingga 12 bulan mendapatkan hasil negatif dan tidak signifikan. Dengan didapatkannya hasil tidak signifikan antara ROA terhadap initial return pada bulan pertama hingga bulan kedua belas, maka menunjukkan besar atau kecilnya ROA perusahaan tidak akan menaikan atau menurunkan initial return pada perusahaan IPO dalam jangka panjang.

Tabel 4

Uji t parsial variable Profitabilitas kinerja perusahaan yang melakukan IPO tahun 2016-2018

\begin{tabular}{|l|l|l|l|l|}
\hline Variabel ROA & Koefisien & $\mathrm{t}$ & $\mathrm{P}>|\mathrm{t}|$ & Hasil \\
\hline Y1 & -0.498195 & -0.57 & 0.572 & Tidak Signifikan \\
\hline Y2 & -0.7577739 & -0.82 & 0.415 & Tidak Signifikan \\
\hline Y3 & -0.7014037 & -0.85 & 0.400 & Tidak Signifikan \\
\hline Y4 & -0.9102826 & -0.72 & 0.475 & Tidak Signifikan \\
\hline
\end{tabular}

Sumber: Hasil Pengolahan Data Stata 15

Profitabilitas yang tidak ada pengaruhnya terhadap initial return ini dikarenakan profit yang dihasilkan perusahaan sebelum IPO tidak menjadi patokan keputusan investor dan salah satu alasan yang mendorong investor tidak melihat profit yang dihasilkan perusahaan sebelum IPO adalah karena ketidak percayaan pihak investor terhadap informasi keuangan perusahaan. Investor akan lebih tertarik untuk melihat kemampuan perusahaan dalam menghasilkan laba setelah perusahaan tersebut melakukan IPO bukan sebelum melakukan IPO.

Alasan dari tidak adanya pengaruh dari profitabilitas terhadap initial return kinerja perusahaan yang melakukan IPO di Bursa Efek Indonesia ini yaitu berasal dari sikap investor itu sendiri. Sikap investor yang membeli saham atau berinvestasi berdasarkan pengalaman, 
bukan berdasarkan analisis fundamental. Bagi investor yang memiliki banyak pengalaman dalam berinvestasi, akan kurang bahkan tidak memperhatikan aspek keuangan yang diinformasikan oleh perusahaan, karena lebih memperhatikan faktor lain contoh aspek pasar atau aspek yang benar-benar terjadi di lapangan yang mana akan jauh lebih berpengaruh dengan initial return yang akan didapatkan jika menyimpan saham tersebut dalam periode waktu jangka panjang.

Hasil dari penelitian ini sema dengan hasil penelitian yang dilakukan Gautama et al. (2015), (Wijayanto, 2010) yang mendapatkan hasil negatif dan tidak signifikan antara variabel ROA terhadap initial return saham IPO. Berbeda dengan hasil penelitian Arman (2011) (Alviani \& Lasmana, 2015) yang menemukan bahwa terjadi hubungan negatif yang signifikan antara ROA dengan return IPO.

\section{Pengaruh financial leverage terhadap kinerja perusahaan yang melakukan IPO di BEI}

Pada penelitian ini variabel financial leverage diukur dengan indikator DER (Debt to Equity Ratio). Pengaruh DER terhadap initial return yang telah diuji secara parsial mendapatkan hasil yang konsisten atau sama yaitu memiliki pengaruh negatif dan signifikan, hal ini dapat dilihat dari nilai koefisien pada bulan pertama sebesar -0.1297232 dengan tingkat signifikan 0.005 lebih kecil dari pada 0.05 , bulan ketiga nilai koefisien sebesar 0.1973581 dengan tingkat signifikan 0.000 lebih kecil dari pada 0.05 , periode waktu 6 bulan nilai koefisien sebesar -0.231057 dengan tingkat signifikan 0.000 lebih kecil dari pada 0.05 , dan periode waktu 12 bulan nilai koefisien sebesar -0.168431 dengan tingkat signifikan 0.012 lebih kecil dari pada 0.05 .

Tabel 5

Uji t parsial variable Profitabilitas kinerja perusahaan yang melakukan IPO tahun 2016-2018

\begin{tabular}{|l|l|l|l|l|}
\hline Variabel DER & Koefisien & $\mathrm{T}$ & $\mathrm{P}>|\mathrm{t}|$ & Hasil \\
\hline Y1 & -0.1297232 & -2.92 & 0.005 & Signifikan \\
\hline Y2 & -0.1973581 & -4.22 & 0.000 & Signifikan \\
\hline Y3 & -0.2031057 & -4.85 & 0.000 & Signifikan \\
\hline Y4 & -0.168431 & -2.62 & 0.012 & Signifikan \\
\hline
\end{tabular}

Sumber: Hasil Pengolahan Data Stata 15

Variabel DER berpengaruh negatif dan signifikan terhadap variabel dependen kinerja IPO artinya apabila investor ingin membeli saham pada saat IPO, akan lebih baik menahan saham tersebut dalam jangka panjang karena investor akan mendapatkan keuntungan dari hari pertama saham diperdagangkan, hingga akhir bulan kedua belas perdagangan.

Perusahaan dengan DER yang tinggi mengindikasikan risiko kegagalan yang tinggi bagi perusahaan, kegagalan perusahaan dalam hal mengembalikan pinjaman begitu juga sebaliknya, semakin rendah DER perusahaan, maka semakin kecil risiko kegagalan dalam mengembalikan pinjaman. Nilai DER dipandang secara berbeda oleh investor, menurut investor DER yang tinggi dipandang sebagai suatu kondisi yang kurang menguntungkan bagi investor.

Penelitian ini menunjukkan bahwa terdapat pengaruh yang signifikan antara financial leverage yang diukur dengan DER terhadap tingkat initial return kinerja IPO, hal inin berarti investor mempertimbangkan nilai DER perudahaan dalam mengambil keputusan berinvestasi pada saat IPO. Mendukung teori yang ada bahwa financial leverage yang tinggi akan menunjukkan resiko finansial bagi para investor, apalagi dalam kinerja jangka panjang atau berinvestasi dalam jangka panjang. Hubungan yang negatif mengartikan semakin tinggi DER 
maka return kinerja IPO akan menurun, sebaliknya semakin rendah DER maka return IPO akan meningkat.

Penelitian ini sepakat dengan penelitian Nuryasinta \& Haryanto (2017). Penelitian ini tidak sepakat dengan penelitian Purwanto, Agustiningsih, Insani, \& Wahyono (2015), (Wijayanto, 2010) yang menyatakan bahwa variabel DER berpengaruh positif dan tidak signifikan terhadap initial return saham IPO.

\section{Kesimpulan}

Variabel reputasi underwriter dalam periode waktu 1 bulan, 3 bulan, dan 12 bulan berhubungan negatif dan tidak signifikan terhadap kinerja IPO. Artinya dalam kinerja IPO, variabel reputasi underwriter mempunyai hubungan yang berlawanan arah dengan return saham IPO, apabila RU semakin tinggi maka tingkat return semakin rendah. Hal yang berbeda terjadi pada bulan ke 6 , terdapat hubungan yang negatif signifikan terhadap return saham IPO.

Variabel underpricing dalam periode waktu 2 bulan terdapat hubungan yang positif dan signifikan, berbeda dengan periode 3 bulan, 6 bulan, dan 12 bulan terdapat hubungan positif dan tidak signifikan terhadap initial return IPO dan terjadi underpricing dalam jangka panjang. Hubungan yang positif ini juga mengartikan terjadi outperformance dalam 12 bulan. Variabel ROA berpengaruh negatif dan tidak signifikan terhadap initial return IPO dalam jangka panjang. Variabel DER pada periode waktu 1 bulan, 3 bulan dan 12 bulan mendapatkan hasil berpengaruh negatif dan signifikan terhadap initial return IPO.

Untuk variabel kontrol dalam penelitian ini menggunakan indikator ASET. Hasil penelitian ini menunjukkan bahwa setiap periode waktu yang telah ditetapkan oleh penulis berhubungan negative dan tidak signifikan terhadap initial return IPO dalam jangka panjang. Karena semakin tinggi total asset perusahaan, maka semakin rendah initial return yang disebabkan oleh total aktiva perusahaan yang besar akan dapat mengurangi risiko perusahaan untuk masa depan perusahaan dimasa yang akan datang.

Berdasarkan hasil pengolahan data, nilai maksimal setiap periode yaitu 1 bulan (Y1), 3 bulan (Y2), 6 bulan (Y3) diperoleh oleh PT Kioson Komersial Indonesia Tbk dan 12 bulan (Y4) diperoleh Indah Prakasa Sentosa Tbk dan terjadi outperformance. Dengan nilai minimal diperoleh oleh PT MAP Boga Adiperkasa Tbk dan terjadi underperformance.

\section{Daftar Pustaka}

Abid, M. T., \& Muharam, H. (2013). Abnormal Return Saham Pada Kinerja Jangka Panjang Penawaran Umum Perdana ( IPO ) ( Studi Kasus Pada Perusahaan Non Finansial Yang Go Public Di Bursa Efek Indonesia Tahun 2006-2009), 10(2).

Adrian, G., Rahardja, M. A., \& Huda, A. N. (2019). Pengaruh Besaran Initial Return Terhadap Performa Jangka Panjang Saham Perusahaan, 2(1), 1-26.

Afriyeni, \& Marlius, D. (2006). Analisis Pengaruh Informasi Prospektus Perusahaan Terhadap Initial Return Saham Pada Pasar Perdana Di Bursa Efek Indonesia, (2006), 117.

Aini, S. N. (2013). Faktor-Faktor Yang Mempengaruhi Underpricing Saham Pada Perusahaan Ipo Di Bei Periode 2007-2011, 1 .

Alshiab, M. S. (2018). Initial Public Offerings Short And Long Term Performance Of MENA Countries, 14(10), 234-251.

Https://Doi.Org/10.19044/Esj.2018.V14n10p234

Alviani, D., \& Lasmana, A. (2015). Analisis Rasio Keuangan Roa, Roe, Price Earning Ratio 
Terhadap Underpricing Saham Perdana. Studi Kasus: Perusahaan Yang Melakukan Ipo Di Bei Periode 2008 - 2011, 1, 1-8.

Andayani, N. S., Wiksuana, I. B., \& Sedana, I. B. P. (2017). Pengaruhnya Terhadap Nilai Perusahaan Pt Garuda Indonesia ( Persero ) TBK, 3, 881-908.

Apriliasari, N. (2013). Perbedaan Kinerja Keuangan Jangka Pendek, Jangka Menengah, Dan Jangka Panjang Pada Perusahaan Yang Melakukan Ipo, 1-18.

Arman, A. (2011). Pengaruh Umur Dan Ukuran Perusahaan, Reputasi Underwriter, Dan Return On Equity Terhadap Tingkat Underpricing Saham Di Bursa Efek Indonesia, 107-120.

Assari, H. N., Juanda, A., \& Suprapti, E. (2014). Roe , Reputasi Auditor , Dan Reputasi Underwriter Terhadap Tingkat Underpricing Saham Pada Saat IPO Di BEI, 4(1), 545554.

Bhatia, S., \& Singh, B. (2018). A Study On The Long-Run Performance Of Initial Public Offerings In India A Study On The Long-Run Performance Of Initial Public Offerings In India Dr. Shikha Bhatia Amity Institute Of Competitive Intelligence, (April). Https://Doi.Org/10.2139/Ssrn.2926872

Brav, A., \& Gompers, P. A. (1997). American Finance Association Myth Or Reality? The Long-Run Underperformance Of Initial Public Offerings : Evidence From Venture And Nonventure Capital-Backed Companies Author ( $\mathrm{S}$ ): Alon Brav And Paul A . Gompers Source: The Journal Of Finance, Vol . 5, 52(5), 1791-1821.

Budiman, A. (2018). Kinerja Jangka Pendek Dan Jangka Panjang Saham Perusahaan Ipo Di Bursa Efek Indonesia, 2(2), 437-445.

Carter, R. B., Dark, F. H., \& Singh, A. K. (1998). Underwriter Reputation , Initial Returns , And The Long-Run Performance Of IPO Stocks, LIII(1).

Chan, K., Wang, J., \& Wei, K. C. J. (2004). Underpricing And Long-Term Performance Of Ipos In China, 10, 409-430. Https://Doi.Org/10.1016/S0929-1199(03)00023-3

Chen, A., Chen, L.-W., \& Kao, L. (2010). Leverage , Liquidity And IPO Long-Run Performance: Evidence From Taiwan IPO Markets. Https://Doi.Org/10.1108/18347641011023261

Chen, Y., Hung, M., \& Wang, Y. (2017). The Effect Of Mandatory CSR Disclosure On Firm Profitability And Social Externalities: Evidence From China. Journal Of Accounting And Economics.

Https://Doi.Org/10.1016/J.Jacceco.2017.11.009

Corhay, A., Teo, S., \& Article, A. T. R. (2008). The Long Run Performance Of Malaysian Initial Public Offerings ( Ipos ): Value And Growth Effects.

Darpius, Agustin, H., \& Sari, V. F. (2019). Pengaruh Financial Leverage, Profitabilitas Dan Besaran Penawaran Saham Terhadap Initial Return, 1(1), 404-415.

Fitriyani, D., Tiswiyanti, W., \& Prasetyo, E. (2017). Good Corporate Governance Dan Dampaknya Terhadap Kinerja Berdasarkan Balanced Scorecard. Jurnal Akuntansi, 20(3), 91-103. Https://Doi.Org/10.24912/Ja.V20i3.7

Florentina, M. N. (2014). Karakteristik Penawaran Umum Saham Perdana: Kinerja Saham Jangka Pendek Dan Kinerja Saham Jangka Panjang Pada Pasar Modal Indonesia, 1(2), $150-161$.

Gautama, A., Diayudha, L., \& Puspitasari, V. A. (2015). Analisa Faktor-Faktor Yang Mempengaruhi Initial Return Setelah Initial Public Offering ( IPO ), 3(2), 539-550.

Gunawan, M., \& Jodin, V. (2015). Faktor-Faktor Yang Mempengaruhi Tingkat Underpricing Saham Pada Perusahaan Yang Melakukan Initial Public Offering Yang Terdaftar Di Bursa Efek Indonesia, $X X(02), 174-192$.

Hendarsih, I. (2017). Strategi Membeli Initial Public Offering ( IPO ) Di Pasar Modal Perdana Indonesia, $I V(2)$. 
Irfani, A. (2011). A Study Of Financial Performance And Stock Return In IPO Underpricing Phenomenon On The Indonesia Stock Exchange ( IDX ), (Idx), 101-116.

Izfs, R. D., \& Supriatna, N. (2019). Pengaruh Initial Public Offering ( IPO ) Terhadap Kinerja Perusahaan, 7(1), 19-28. Https://Doi.Org/10.17509/Jrak.V7i1.15376

Karo-Karo, S. (2011). Analisis Faktor-Faktor Yang Mempengaruhi Tingkat Ipo Underpricing Di Bursa Efek Indonesia. Jurnal Mediasi.

Kurniawan, D. (2008). Regresi Linier.

Kusumawati, D. (2016). Analisis Kinerja Saham Dalam Jangka Pendek Dan Jangka Panjang Setelah Initial Public Offering ( Ipo ) Di Bursa Efek Indonesia Tahun 2006 - 2016.

Lestari, A. H., Hidayat, R. R., \& Sulasmiyati, S. (2015). Saham Pada Penawaran Umum Perdana Di Bei Periode 2012-2014 ( Studi Pada Perusahaan Yang Melaksanakan IPO Di Bursa Efek Indonesia Periode 2012-2014 ). Jurnal Administrasi Bisnis, 25(1), 1-9.

Meidiaswati, H. (2008). Kinerja Jangka Panjang Pada IPO (Initial Public Offering) Di Indonesia Periode 1991-1993, (2), 184-196.

Murtini, U. (2013). Pengaruh Reputasi Underwriter, Size Dan Usia Perusahaan Pada Penentuan Harga Ipo, (2012), 137-146.

Nuryasinta, A., \& Haryanto, M. (2017). Analisis Faktor-Faktor Yang Mempengaruhi Initial Return Pada Perusahaan Non Keuangan Yang Melakukan Initial Public Offering ( IPO ) Di Bei Periode, 6, 1-11.

Octaviani, S. (2016). Faktor - Faktor Yang Mempengaruhi Return Saham Pada Emisi Saham Perdana. Jurnal Akuntansi. Vol. 3 No. 2. Juli 2016, 3(2), 40-53.

Oktavia, H. C. A., Wijaya, A. L., \& Sudrajat, M. A. (2019). Analisis Pengaruh Leverage , Profitabilitas, Likuiditas Saham, Dan Reputasi Underwriter Terhadap Underpricing Ipo, (2012), 502-513.

Que, J., \& Zhang, X. (2019). Pre-IPO Growth, Venture Capital, And The Long-Run Performance Of Ipos. Economic Modelling.

Https://Doi.Org/10.1016/J.Econmod.2019.04.005

Riantani, S., \& Yuliani, R. (2010). Analisis Kinerja Saham Perusahaan-Perusahaan Yang Melakukan Initial Public Offering ( IPO ).

Ritter, J. A. Y. R. (1991). The Long-Run Performance Of Initial Public Offerings, XLVI(1), $3-27$.

Ritter, J. R. (1991). The Long-Run Performance Of Initial Public Offerings, XLVI(1), 3-27.

Santoso, E., \& Wuryani, E. (2013). Analisis Pengaruh Kinerja Keuangan, Ukuran Perusahaan, Reputasi Underwriter Dan Reputasi Auditor Terhadap Initial Return, 1.

Sholichah, M. (1991). The Company Characteristics, Initial Return And Long Term Performance Stock Initial Public Offerings Listing In Indonesia Stock Exchange, 6(3), 988-997. Https://Doi.Org/10.21474/IJAR01/6756

Suherman. (2015). Kinerja Jangka Panjang Dan Likuiditas Pasca Ipo Di Papan Utama Dan Pengembangan Bursa Efek Indonesia Suherman, 19(1), 30-40.

Suherman, Rizkiyah, W., \& Buchdadi, A. D. (2007). Kinerja Jangka Panjang Ipo Di Papan Utama Dan Pengembangan, 1-16.

Suliyanto. (2017). Metode Penelitian Kuantitatif, 1-39.

Sundarasen, S. D. D., \& Sundarasen, S. D. D. (2019). Institutional Characteristics , Signaling Variables And IPO Initial Returns A Study On OECD Countries. Https://Doi.Org/10.1108/PRR-10-2016-0003

Surbakti, L. (2012). Earnings Management, Underpricing, Dan Underperformance Pada Initial Public Offering Di Indonesia.

Teoh, S. H., Welch, I. V. O., Wong, T. J., Aharony, J., Barber, J., Bernard, V., ... Titman, S. (1998). Earnings Management And The Long-Run Market Performance Of Initial Public Offerings, LIII(6). 
Utamaningsih, A. (2014). Pengaruh Aktivitas Pasar Dan Reputasi Underwriter Terhadap Excess Returns Saham Ipo Di Bursa Efek Indonesia, 3(September).

Warganegara, D. L., \& Indriastari, I. (2009). Article Information: Do Indonesian Firms Inflate Their Reported Earnings Prior To Ipos?

Widarjo, W. (2011). Jurnal Akuntansi Dan Keuangan Indonesia Pengaruh Modal Intelektual Dan Pengungkapan Modal, 8(2), 157-170.

Wijayanto, A. (2010). Analisis Pengaruh Roa, Eps, Financial Leverage, Proceed Terhadap Initial Return, $1(1), 68-78$.

Y.S, S. P., Thoyib, A., \& Idrus, M. S. (2010). Analisis Reaksi Pasar Modal Setelah Pengumuman Initial Public Offering (Ipo) Pada Perusahaan Yang Terdaftar Di Bursa Efek Jakarta, 13(3).

Yasa, G. W. (2002). Penyebab Underpricing Pada Penawaran Saham Perdana Di Bursa Efek Jakarta, 1-29.

Yip, Y., Su, Y., \& Ang, J. B. (2009). Article information: Effects of Underwriters, Venture Capital and Industry on Long-Term Initial Public Offering Performance.

Yuliani, Wahyuni, D., \& Bakar, S. W. (2019). The Influence Of Financial And Non financial Information To Underpricing Of Stock Prices In Companies That Conduct Initial Public Offering, 3, 39-51.

Yusniar, M. W. (2016). Kinerja Harga Saham Jangka Pendek Dan Jangka Panjang Setelah Penawaran Saham Perdana ( IPO ), 187-204. 